Eur. J. Clin. Chem. Clin. Biochem.

Vol. 29, 1991, pp. 317-320

(C) 1991 Walter de Gruyter \& Co. Berlin - New York

\title{
Effects of Vitamin A Status on Cellular Retinoic Acid-Binding Protein in Rat Skin and Testes
}

\author{
By K. A. Madani, ${ }^{1,2}$ G. S. Bazzano ${ }^{1,2}$ and A. C. Chou ${ }^{1,2}$ \\ 1 Tulane University School of Public Health and Tropical Medicine \\ 2 Touro Research Institute, New Orleans, Louisiana, U.S.A.
}

(Received April 4, 1989//February 2/December 12, 1990)

Summary: Cellular retinoic acid-binding protein levels were determined in the skin and testes of normal and retinol-deficient rats. All-trans $\left[{ }^{3} \mathrm{H}\right]$ retinoic acid $(1.1 \mathrm{TBq} / \mathrm{mmol})$ was used to titrate the specific binding sites in tissue cytosol preparations. Scatchard plot analyses were used to determine the concentration of cellular retinoic acid-binding protein and its binding affinity $\left(\mathrm{K}_{\mathrm{d}}\right)$ for all-trans-retinoic acid. In normal rat skin the concentration of cellular retinoic acid-binding protein was $3317 \pm 924$ (SD) fmol/mg protein and the $K_{d}$ was $1.98 \pm 1.0 \times 10^{-9} \mathrm{~mol} / 1$. In retinol-deficient rat skin the concentration of cellular retinoic acid-binding protein was $2584 \pm 1205 \mathrm{fmol} / \mathrm{mg}$ protein and the $K_{d}$ was $3.30 \pm 3.4 \times 10^{-9} \mathrm{~mol} / \mathrm{l}$. In the normal rat testes the concentration of cellular retinoic acid-binding protein was $2965 \pm 1187 \mathrm{fmol} / \mathrm{mg}$ protein and the $\mathrm{K}_{\mathrm{d}}$ was $2.30 \pm 2.1 \times 10^{-9} \mathrm{~mol} / \mathrm{l}$. In retinol-deficient rat testes the concentration of cellular retinoic acid-binding protein was $2439 \pm 383 \mathrm{fmol} / \mathrm{mg}$ protein and the $\mathrm{K}_{\mathrm{d}}$ was $0.3 \pm 0.2 \times 10^{-9} \mathrm{~mol} / \mathrm{l}$. These findings indicate that there are no significant differences in the levels of cellular retinoic acid-binding protein between normal and deficient rat skin and testes $(p>0.1$, by Wilcoxon rank sum test). We therefore conclude that the level of cellular retinoic acid-binding protein in skin and testes may not be controled by the availability of vitamin $\mathrm{A}$.

\section{Introduction}

The molecular action of retinoids is not yet known, although there is growing evidence that retinoids affect cell differentiation and proliferation, and may affect gene expression in target cells $(1-3)$. All-transretinoic acid is a natural metabolite formed from retinol and retinaldehyde. It possesses many of the biological activities of vitamin $\mathrm{A}$, and is transported by cellular retinoic acid-binding protein. This specific cytoplasmic binding protein appears to be involved in the function of retinoic acid (4-6). However, the newly discovered nuclear receptor for retinoic acid $(7-9)$ is more important in the mechanism of action of retinoic acid at the genome level. It is still important to understand how the biological activity of various derivatives of retinoic acid correlates with their binding affinity for cellular retinoic acid-binding protein $(10-12)$ and for the nuclear receptor. More information is also needed about the factors that regulate the levels of the cellular retinoic acid-binding protein. We therefore designed this study to further elucidate how the vitamin A nutritional status affects the levels of cellular retinoic acid-binding protein in rat skin and testes.

\section{Materials and Methods}

Chemicals

The all-trans $\left[{ }^{3} \mathrm{H}\right]$ retinoic acid $(1.1 \mathrm{TBq} / \mathrm{mmol})$ and the nonlabelled all-trans-retinoic acid were generous gifts from Hoffmann-La Roche Drug Company, Nutley, NJ; Dextran TMO was from Pharmacia Fine Chemicals, Uppsala, Sweden; Triton X-100 from Sigma Chemical Corp., St. Louis, MO; Toluene and norit A (Charcoal), from Baker Chemical Co., Phillipsburg, NJ; omnifluor from New England Nuclear, Boston, MA; retinyl acetate (reference) from Eastman, Kodak Co., Rochester, NY. The radioactive retinoic acid was stored in solution in toluene at $-70^{\circ} \mathrm{C}$. To prepare the radioactive retinoic acid for use, the toluene was removed by evaporation under a stream of nitrogen, and all-trans $\left[{ }^{3} \mathrm{H}\right] \mathrm{retinoic}$ acid was purified by high-performance liquid chromatography (HPLC). 


\section{Animals and dicts}

Sprague-Dawley rats were purchased from Charles River, Willington. MA; the vitamin A deficient diet from National Biochemicals. Cleveland, $\mathrm{OH}$; the control diet from Ralston Purina Company. St. Louis, MO.

The offspring of 10 pregnant female Sprague-Dawley rats were randomly assigned, after delivery, to two groups; one group ivas fed a vitamin A-deficient diet, the other was fed a control diet. Food and water were provided ad libitum. As soon as the nursing rats in the study group were weaned, they were put on deficient diets, while those in the control group were put on normal diets for 8 weeks.

\section{Assessment of vitamin A mutritional status}

Tissue vitamin A content was determined by the trifluoroacetic acid method of Dugan et al. (13) after ether extraction according to Ames et al. (14). This method was satisfactory for our purposes, although the HPLC method is even more quantitative.

\section{Cytosol preparation}

All operations were performed as quickly as possible over crushed ice. Rat testes or skin (1 g) was placed in $4 \mathrm{ml}$ of cold $2 \mathrm{mmol} / \mathrm{l}$ Tris/ $\mathrm{HCl}$ buffer, $\mathrm{pH} 7.5$, and $1 \mu \mathrm{l}$ monothioglycerol was added per $\mathrm{ml}$ of buffer. The tissue was homogenized by a few strokes in a Polytron homogenizer with intermittent cooling.

The homogenate was transferred to $10 \mathrm{ml}$ cellulose nitrate tubes. placed in a type 50 Beckman rotor and centrifuged at $100000 \mathrm{~g}$ for $30 \mathrm{~min}$ at $4{ }^{\circ} \mathrm{C}$ in a Beckman model L-2-65 ultracentrifuge (Palo Alto, California).

The cellular retinoic acid-binding protein was further partially purified by adjusting the $\mathrm{pH}$ of the supernatant layer to 5 , followed by centrifugation at $100000 \mathrm{~g}$ for $30 \mathrm{~min}$ at $4^{\circ} \mathrm{C}$. The supernatant was removed and adjusted to $\mathrm{pH} 7.2$ with $5 \mathrm{~mol} / \mathrm{l}$ $\mathrm{NaOH}$, and kept on ice.

The protein concentration was determined by the method of Waddel (15).

All of the data were ultimately expressed per milligram of protein.

\section{Determination of cellular retinoic acid-binding protein by radio-} receptor assay

Stock solutions $(2 \mu \mathrm{mol} / \mathrm{l})$ of $\left[{ }^{3} \mathrm{H}\right]$ retinoic acid in dimethyl sulphoxide were serially diluted to give concentrations of $0: 5$ $\mu \mathrm{mol} / \mathrm{l}, 0.125 \mu \mathrm{mol} / \mathrm{l}, 0.0625 \mu \mathrm{mol} / \mathrm{l}, 0.0315 \mu \mathrm{mol} / 1$ and 0.0157 $\mu \mathrm{mol} / \mathrm{l}$. Aliquots $(10 \mu \mathrm{l})$ of each of the 5 dilutions were added to $100 \mu \mathrm{l}$ cytosol in the presence and absence of 200 -fold molar excess of unlabelled retinoic acid. After 18-24 hours of incubation at $4{ }^{\circ} \mathrm{C}$ in the dark, the binding of retinoic acid to receptor was assumed to be at equilibrium. The final incubation mixtures contained $16.6,4.1,2.0,1.0$, and $0.5 \mathrm{nmol} / \mathrm{l}$ $\left[{ }^{3} \mathrm{H}\right] \mathrm{retinoic}$ acid. All incubation were performed in duplicate. To determine the amount of labelled retinoic acid bound by the unknown quantity of receptor, the unbound retinoic acid was removed from the system by adding $0,6 \mathrm{ml}$ ice-cold dextrancoated charcoal suspension to each tube, followed by constant stirring in an ice-bath for 20 minutes (16).

The primary purpose of partially purifying the cellular retinoic acid-binding protein was to remove interfering substances that bind $\left[{ }^{3} \mathrm{H}\right]$ retinoic acid non-specifically, thus enabling use of the rapid assay based on charcoal absorption of the unbound ligand.

The tubes were then centrifuged at $2200 \mathrm{~g}$, for $8-10$ minutes at $4{ }^{\circ} \mathrm{C}$. Then $0.5 \mathrm{ml}$ of supernatant was carefully withdrawn and transferred to a mini vial, followed by addition of $4 \mathrm{ml}$ of toluene-Triton cocktail $(600 \mathrm{ml}$ Triton X-100,1400 ml toluene and $8 \mathrm{~g}$ omnifluor). All vials were counted for 4 minutes in a Packard model 2405 liquid scintillation counter.

A Scatchard plot was constructed by plotting the ratio, bound/ free radioactivity (B/F), against specifically bound retinoic acid. Linear regression analyses of the data provided the number of specific binding sites and the cytosol binding protein affinity to retinoic acid $\left(\mathrm{K}_{\mathrm{d}}\right)$. The $\mathrm{r}$ value was the best straight line (least squares regression) through each set of points.

\section{Results}

The mean level of vitamin $\mathrm{A}$ in the liver of rats fed a control diet was $40.7 \mu \mathrm{g} / \mathrm{g}$, and in the plasma 380 $\mu \mathrm{g} / \mathrm{l}$, while the level of vitamin $\mathrm{A}$ in the liver of rats fed vitamin A-dificient diets for 8 weeks was undetectable and the plasma level was $47 \mu \mathrm{g} / 1$.

Results of five separate experiments using rat skin, and of three separate experiments using rat testes are shown in table 1 and a typical example is shown in figure 1.

In the normal rat skin, the $K_{d}$ value was $1.98 \pm 1.0$ (SD) $\times 10^{-9} \mathrm{~mol} / \mathrm{l}$ and the number of binding sites was $3317 \pm 924 \mathrm{fmol} / \mathrm{mg}$ protein. In retinol-deficient rat skin, the $K_{d}$ was $3.30 \pm 3.4 \times 10^{-9} \mathrm{~mol} / 1$ and the number of binding sites was $2584 \pm 1205 \mathrm{fmol} / \mathrm{mg}$ protein. There is therefore no significant difference in the levels of cellular retinoic acid-binding protein be-

Tab. 1. Dissociation constant and cellular retinoic acid-binding protein levels in normal and vitamin A-deficient rat skin and testes.

\begin{tabular}{|c|c|c|c|c|c|}
\hline Type of tissues & $\mathrm{n}$ & & $\begin{array}{l}\mathrm{K}_{\mathrm{d}} \\
(\text { mean } \pm \mathrm{SD}) \\
{\left[10^{-9} \mathrm{~mol} / \mathrm{l}\right]}\end{array}$ & $\begin{array}{l}\text { No. of sites } \\
\text { [fmol/mg protein] }\end{array}$ & $r$ \\
\hline Rat skin & (5) & $\begin{array}{l}\text { normal } \\
\text { vitamin A-deficient }\end{array}$ & $\begin{array}{l}1.98 \pm 1.0 \\
3.30 \pm 3.4\end{array}$ & $\begin{array}{l}3317 \pm 924 \\
2584 \pm 1205\end{array}$ & $\begin{array}{l}0.85 \pm 0.05 \\
0.90 \pm 0.03\end{array}$ \\
\hline Rat lestes & (3) & $\begin{array}{l}\text { normal } \\
\text { vitamin A-deficient }\end{array}$ & $\begin{array}{l}2.30 \pm 2.1 \\
0.30 \pm 0.2\end{array}$ & $\begin{array}{l}2965 \pm 1187 \\
2439 \pm 383\end{array}$ & $\begin{array}{l}0.93 \pm 0.03 \\
0.95 \pm 0.03\end{array}$ \\
\hline
\end{tabular}

The $r$ value is the correlation coefficient.

$\mathrm{n}$ indicates the number of experiments. 


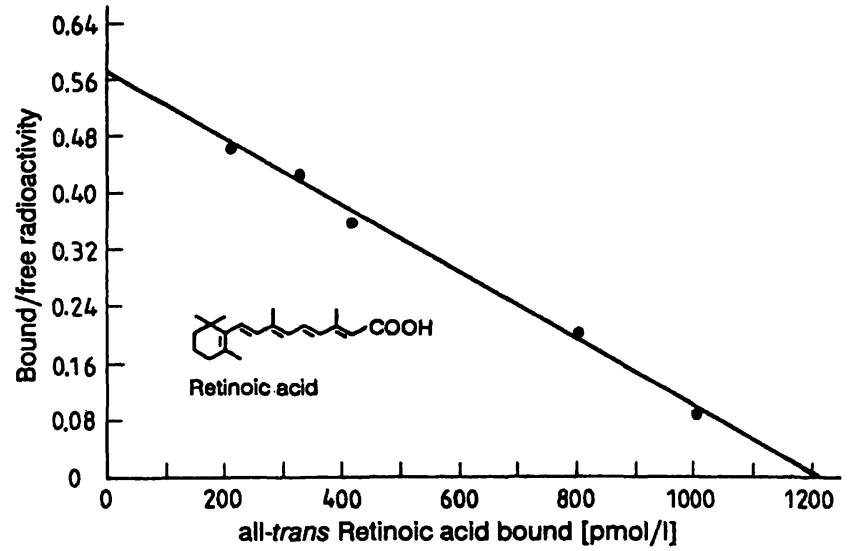

Fig. 1. Scatchard analysis of the specific binding of all-trans $\left[{ }^{3} \mathrm{H}\right] \mathrm{retinoic}$ acid to receptor from partially purified cytosol of normal rat skin in the presence of 200-fold unlabelled all-trans-retinoic acid. The line was determined by linear regression analysis. The $\mathrm{K}_{\mathrm{d}}$ was calculated from the slope of the line. The number of specific binding sites was determined from the intercept on the abscissa.

tween normal and deficient rat skin by the Wilcoxon rank sum test $(p>0.1)$.

In the testes, the $K_{d}$ values were $2.30 \pm 2.1 \times 10^{-9}$ $\mathrm{mol} / \mathrm{l}$ and $0.3 \pm 0.2 \times 10^{-9} \mathrm{~mol} / \mathrm{l}$, the number of binding sites were $2965 \pm 1187 \mathrm{fmol} / \mathrm{mg}$ and 2439 $\pm 383 \mathrm{fmol} / \mathrm{mg}$ protein in the normal and vitamin A deficient rat testes, respectively. This indicates that there is no significant difference in the levels of cellular retinoic acid-binding protein between normal and vitamin A-deficient rat testes by Wilcoxon rank sum test $(p>0.1)$.

\section{Discussion}

It is now assumed that cytosolic retinoic acid-binding proteins are probably shuttles that carry retinoic acid to the nuclear receptors, which are now known to be the true receptors that affect the action of retinoic acid at the genome $(3,18)$.

Nevertheless, the biological activity of various retinoids may be related to binding by cellular retinoid binding proteins in the target tissues $(19-21)$. Therefore, we have attempted to further clarify the effect of vitamin A nutritional status on the levels of cellular retinoic acid-binding protein in rat skin and testes.

It has been shown (22) that retinoid-deficient rats showed reduced tissue levels of cellular retinol-binding protein. Cellular retinoic acid-binding protein levels, however, were not affected by differences in retinoid nutritional status, except in the skin, where cellular retinoic acid-binding protein levels appear to be minimally influenced by the amount of retinoid ligands available. This minimal change in the level of cellular retinoic acid-binding protein probably arises from methodological differences between the previous study and the present study. These differences may lie in the tissue preparation or in the conduct of the radioligand assay. The amounts of both cellular retinol-binding protein and cellular retinoic acid-binding protein in testes are similar for retinol-depleted and pair-fed control rats (23), using sucrose gradient centrifugation. Sundelin et al. (24) found similar levels of cellular retinoic acid-binding protein in the testes of normal and retinol-deficient (supplemented with retinoic acid) rats; in contrast, there was a marked decrease in cellular retinol-binding protein and an increase in cellular retinoic acid-binding protein of both corneal, and conjunctival epithelia in retinoldeficient rabbits (24), using the sucrose gradient assay.

Siegenthaler et al. (25) reported that cellular retinoic acid-binding protein and not cellular retinol-binding protein is significantly elevated in psoriatic plaques, compared with either non-lesional psoriatic skin or normal controls, using the charcoal-dextran and gel filtration assays. The level of cellular retinoic acidbinding protein, but not cellular retinol-binding protein, is augmented during oral administration of the synthetic retinoid, Etretin (Ro 10-1670), in non-lesional psoriatic skin, using the charcoal-dextran and gel filtration assays. This suggests that synthetic retinoid therapy may affect the regulation of the natural retinoic acid-binding proteins in human skin (26).

In this study, when retinol-deficient rats were compared with pair-fed controls, no significant differences were observed in the levels of cellular retinoic acidbinding proteins in either testes or skin. It would therefore appear that the level of these binding proteins may not be controlled by the low availability of vitamin A. It has been proposed that cellular retinoic acid-binding protein may serve as a means of detoxification or elimination of excess retinoid (27).

In the present study, the $K_{d}$ values ranged from $10^{-8}$ to $10^{-10} \mathrm{~mol} / \mathrm{l}$, which indicates a high affinity of binding of all-trans-retinoic acid to cellular retinoic acid-binding protein in the tissues studied. Our data on the affinity for cellular retinoic acid-binding protein are in agreement with other studies $(10,25,26)$.

The possible role played by cellular receptors in mediating the pharmacological effects of retinoids is still unclear. More information is needed concerning the interaction between the retinoids and their receptors.

\section{Acknowledgement}

This work was supported by grants from the Saudi Arabian Government, Hoffman-La Roche, and the Glazer Mcdical Fund. 


\section{References}

1. Madani, K. A. (1988) Role of vitamin A in cellular differentiation. Int. Clin. Nut. Rev. 52, 75-80.

2. Sporn, M. B. \& Roberts, A. M. (1983) Role of retinoids in differentiation and carcinogenesis. Cancer Res. 43, 30343040.

3. Bedo, G., Santisteban, P. \& Aranda, A. (1989) Retinoic acid regulates growth hormone gene expression. Nature $339,231-234$.

4. Chytil, F. \& Ong, D. (1976) Mediation of retinoic acidinduced growth and antitumor activity. Nature 260, 49-51.

5. Jetten, A. M., Jetten, M. E., Shapiro, S. S. \& Poon, J. P. (1979) Characteristics of the action of retinoids on mouse fibroblast cell lines. Exp. Cell Res. 119, 289-301.

6. Sani. B. P., Titus, B. C. \& Banerjee, C. K. (1978) Determination of binding affinities of retinoids to retinoic acidbinding protein and serum albumin. Biochem. J. 171, $711-$ 717.

7. Brand, N., Petkovich, M., Krust, A., Chambon, P., de Thé, H.. Marchio, A. \& Dejean, A. (1988) Identification of a second human retinoic acid receptor. Nature 332, 850853.

8. Benbrook, D., Lernhardt, E. \& Pfahl, M. (1988) A new retinoic acid receptor identified from a hepatocellular carcinoma. Nature 333, 660-672.

9. Giguere, V., Ong, E. S., Segui, P. \& Evans, R. M. (1987) Identification of a receptor for the morphogen retinoic acid. Nature 330, 624-629.

10. Madani, K. A., Bazzano, G. S. \& Chou, A. C. (1986) Evaluation of retinoids as inhibitors of all-trans $\left[{ }^{3} \mathrm{H}\right]$ retinoic acid binding to cellular retinoic acid-binding protein in rat skin and testes. Arch. Dermatol. Res. 278, 302-306.

11. Lotan, R., Neumann, G. \& Lotan, D. (1980) Relationship among retinoid structure, inhibition of growth, and cellular retinoic acid-binding protein in cultured S91 melanoma cells. Cancer Res. 40, 1097-1102.

12. Jetten, A. M. \& Jetten, M. E. (1979) Possible role of retinoic acid-binding protein in retinoic acid stimulation of embryonal carcinoma cell differentiation. Nature 278, 180182.

13. Dugan, R. E., Frigerio, N. A. \& Siebart, J. M. (1964) Colorimetric determination of vitamin $\mathrm{A}$ and its derivatives with trifluoroacetic acid. Anal. Chem. 36, 114-117.

14. Ames, S. T., Risley, H. A. \& Harris, P. L. (1954) Simplified procedure for extraction and determination of vitamin A in liver. Anal. Chem. 26, 1378-1381.

15. Waddel, W. (1968) A simple ultraviolet spectrophotometric method for the determination of protein. J. Lab. Clin. Med. $48,311-324$.
16. Trown, P. W., Palleroni, A. V., Bohoslawec, O., Richelo, B. N., Halpren, J. M., Machilin, L. J., Jetten, A. M. \& Jetten, M. E. (1980) Relationship between binding affinities to cellular retinoic acid-binding protein and in vivo and in vitro properties for 18 retinoids. Cancer Res. 40, 212-220.

17. Scatchard, G. (1949). The attraction of proteins for small molecules and ions. Ann. N. Y. Acad. Sci. 51, 660-672.

18. Umesono, K., Giguere, V., Glass, C. K., Rosenfeld, M. G. \& Evans, R. M. (1988) Retinoic acid and thyroid hormone induce gene expression through a common responsive element. Nature 336, 262-265.

19. Fuchs, E. \& Green, H. (1981) Regulation of terminal differentiation of cultured human keratinocytes by vitamin $\mathrm{A}$. Cell 25, 617-635.

20. Madani, K. A. \& Elmongy, M. B. (1986) Role of vitamin A in cancer. Nutr. Res. 6, 863-875.

21. Cadi, R., Pautou, M. P. \& Dhonailly, D. (1984) Structureactivity relationships of retinoids in the morphogenesis of cutaneous appendages in the chick embryo. J. Invest. Dermatol. 83, 105-109.

22. Kato, M., Blaner, W. S., Mertz, J. R., Das, K., Kato, K. \& Goodman, D. S. (1984) Influence of retinoid nutritional status on cellular retinol- and cellular retinoic acid-binding protein concentrations in various rat tissues. J. Biol. Chem. $260,4832-4835$.

23. Ong, D. E., Tsai, C. H. \& Chytil, F. (1976) Cellular retinolbinding protein and cellular retinoic acid-binding protein in rat testes: Effect of retinol depletion. J. Nutr. 106, 204211.

24. Sundelin, J., Busch, C., Das, K., Eriksson, U., Johnson, K. H., Kampe, O., .Laurent, B., Liljas, A., Newcomer, M., Nilsson, M., Norlinder, H., Rask, L., Ronne, H. \& Peterson, P. A. (1983) Structure and tissue distribution of some retinoid-binding proteins. J. Invest. Dermatol. $81,59 \mathrm{~S}-$ $63 \mathrm{~S}$.

25. Siegenthaler, G., Saurat, J. H., Hotz, R., Camenżind, M. \& Merot, V. (1986) Cellular retinoic acid- but not cellular retinol-binding protein is elevated in psoriatic plaques. J. Invest. Dermatol. 86, 42-45.

26. Siegenthaler, G. \& Saurat, J. H. (1986) Therapy with a synthetic retinoid (Ro 10-1670) Etretin - increase the cellular retinoic acid-binding protein in non-lesional psoriatic skin. J. Invest. Dermatol. 87, 122-124.

27. Siegenthaler, G. \& Saurat, J. H. (1987) Plasma and skin carriers for natural and synthetic retinoids. Arch. Dermatol. $123,1690 \mathrm{~S}-1692 \mathrm{~S}$

Dr. Khalid A. Madani

P.O. Box 2183

Jeddah, 21451

Saudi Arabia 